\title{
Atatürk Dönemi Türkiye Cumhuriyeti Ille Mao Zedong Dönemi Çin Halk Cumhuriyeti'nin Ulus Devletleşme Sürecinin Karşılaştırmalı Analizi
}

\section{A Comparative Analysis of The Process of Nation State Formation of The Republic of Turkey at The Period of Ataturk and The People's Republic of China in The Period of Mao Zedong}

\author{
İsmail Sevinc ${ }^{1 *}$ (D) Hande Karamanoğlu ${ }^{1}$ (iD)
}

${ }^{1}$ Department of Politics and Public Administration, Necmettin Erbakan University, Konya, Turkey

\begin{abstract}
Received: 19.10 .2021
Accepted: 20.12 .2021

This article was checked by intihal.net

Öz

Türkiye Cumhuriyeti ile Çin Halk Cumhuriyeti, birçok noktada benzerlik taşımasına karşın akademik çalışmaların bu konuda yeterli olmadığı görülmektedir. Bu duruma ışık tutmak için çalışmada ulus devletleşme sürecinde Türkiye ve Çin Halk Cumhuriyeti'nin benzerlikleri ve farklılıkları ortaya konularak bunların arkasındaki itici güçlerin belirlenmesi amaçlanmışır. 21. yüzyılın en büyük ekonomilerinden olan Çin Halk Cumhuriyeti, siyasi birliğini Türkiye'ye göre çok geç sağlamış olmasına ve Mao Zedong'un devrimlerinin başarısız kabul edilmesine rağmen önemli ilerlemeler kaydetmiştir. Buna karşılık Türkiye Cumhuriyeti siyasi birliğini hızı bir şeklide sağlayarak günümüzün önemli devletlerinden biri olmuştur. Birinci Dünya Savaşından sonra ulus devletleşme sürecinde Türkiye Cumhuriyeti ve Çin Halk Cumhuriyeti, imparatorluk rejiminden koparak ulus inşa etme çalışmalarına başlamışlardır. Araştırmada dönemin özellikleri, her bir ülke için ayrı ayrı değerlendirilmiş, daha sonra karşılaştırmalı olarak analiz edilmiştir. Ulus devletleşme döneminin iki ülke açısından etkileri, tek parti rejimi, iç politika, dış politika, devrimler ve bürokrasi konuları altında değerlendirilmiştir. Sonuç olarak merkezileşme akımının etkileriyle değişen dünya düzenine biri cumhuriyet diğeri komünizm ile başlamış olsa da güçlü bir imparatorluktan dönüşmeleri, tarım toplumu olmaları, köylüye dayalı iktidarın sağlanmaya çalışılması ve ülkelerin dünyadaki gelişmelere ayak uyduramamaları konularında benzerlik gösterdikleri ifade edilebilir.
\end{abstract}

Anahtar Kelimeler: Mustafa Kemal Atatürk, Mao Zedong, Ulus devletleşme

\section{Abstract}

Although the Republic of Turkey and the People's Republic of China have similarities in many perspectives, it is seen that academic studies are not sufficient in this regard. In order to shed light on this situation, the aim of this study is to reveal the similarities and differences of Turkey and the People's Republic of China in the nation-stateization process and to determine the driving forces behind them. The People's Republic of China, one of the largest economies of the 21st century, has made significant progress despite the fact that it achieved its political unity much later than Turkey and that Mao Zedong's revolutions were considered unsuccessful. On the other hand, the Republic of Turkey has become one of the most important states of today by providing its political unity quickly. After the First World War, in the nation-stateization process, the Republic of Turkey and the People's Republic of China started to build a nation by breaking away from the imperial regime. In the research, the characteristics of the period were evaluated separately for each country and then analyzed comparatively. The effects of the nation-stateization period for the two countries were evaluated under the single-party regime, domestic policy, foreign policy, revolutions and bureaucracy. As a result, it can be stated that adoption to the changing world order, which was influenced by the centralization movement, in both countries started with one with republic and the other with communism, they are similar in terms of their transformation from a strong empire, being an agricultural society, trying to provide power based on peasants, and countries' inability to keep up with the developments in the world.

Keywords: Mustafa Kemal Ataturk, Mao Zedong, Nation-stateization

Sevinc, I. \& Karamanoğlu, H. (2021). Atatürk Dönemi Türkiye Cumhuriyeti ile Mao Zedong Dönemi Çin Halk Cumhuriyeti'nin Ulus Devletleşme Sürecinin Karşılaştırmalı Analizi. Journal of Academic Value Studies, 7(4), 416-428. http://dx.doi.org/10.29228/javs.53901

\footnotetext{
E-mail: isevinc@erbakan.edu.tr (Corresponding Author)
} 


\section{Giriş}

Birinci Dünya Savaşı'ndan sonra küresel bir hareket olarak ulus bilincinin artması ve buna bağlı olarak tebaa anlayışına sahip imparatorlukların yıkılıp yerlerine yeni devletlerin kurulduğu görülmektedir. Bu süreç, her ülke için hemen hemen birbirine yakın tarihlerde başlasa da aynı şekilde devam etmemiştir. 20. yüzyıla kadar büyük bir imparatorluğa sahip olan Türkiye ve Çin ulus devletleşme sürecini sancılı atlatmış ve bağımsız bir devlet olabilmeyi başarmışlardır. Dönemin güçlü devletlerinin baskıları sonucunda yaşanan gelişmelerin yanında, iki güçlü lider Mustafa Kemal Atatürk ve Mao Zedong önderliğinde iki ülkede de önemli toplumsal ve siyasal değişimler ortaya çıkmıştır.

Çin Halk Cumhuriyeti, Türkiye'ye göre iç karışıklıklarını daha geç çözebilmiş, bu yüzden 1949 yılına kadar siyasi birliğini sağlayamamıştır. İkinci Dünya Savaşı́nın da etkisiyle savaşlarla bölünen bağımsız bir devlet kurma çabasını Mao Zedong üstlenmiştir. İmparatorluk rejiminin yıkılmasından sonra Türkiye gibi cumhuriyet rejimi kurmak isteyen Sun Yat-sen iktidara gelmiş fakat askeri gücünün zayıf olmasından dolayı başarılı olamamıştır. Kişisel idealler konusunda Çin'in Atatürk'ü de denilen Sun Yat-sen'den sonra gelen Mao Zedong bağımsız bir devlet kurabilmiş, ideolojik olarak Sun Yat-sen'in aksine cumhuriyet yerine komünizmi benimsemiştir.

İki ülkenin karşılaştırmalı analizi yapılırken Sun Yat-sen döneminin alınmamış olması ulus devletleşme sürecinin O'nun döneminde henüz tamamlanmamış olmasından dolayıdır. Her ne kadar ideolojiler farklı olsa da ulus devletleşme dönemini başlatan ve Türkiye ile benzer sorunlar yaşanan dönem Mao Zedong'un dönemi olmuştur. Çalışmada öncelikli olarak Atatürk dönemi Türkiye'sinin tek partili siyasal yaşamı, iç ve dış politikası, devrimleri ve bürokrasi kurma çabası anlatılmış, daha sonra aynı başlıklar Çin Halk Cumhuriyeti için de açıklanmaya çalışılmıştır. Çalışmanın son bölümünde ise iki ülkenin karşılaştırmalı analizi yapılmış ve hangi konularda neden benzedikleri ya da neden farklı oldukları ortaya konulmaya çalışılmıştır.

\section{Cumhuriyet Halk Partisi ve Tek Partili Siyasal Yaşam}

Türkiye Cumhuriyeti'nde Cumhuriyet Halk Partisi (CHP), iktidarının meşruiyetini, ülkeyi kurtaran Müdafaa-i Hukuk temelinden gelmiş olmaları ve tüm toplumsal kesimleri temsil ettikleri iddiası olmak üzere iki temel üzerine kurgulamıştır. Müdafaa-i Hukuk Cemiyeti ülkeyi düşmandan kurtarmış ve misyonunu tamamlamış, cemiyetin devamı olarak ülkenin bir daha bu tehlikeyle karşılaşmaması için de devletin ve toplumun modernleşmesi misyonuna sahip CHP iktidara gelmiştir. CHP, halkın partisi olarak Türkiye'de bulunan tüm sınıfsal kesimlerin temsil edildiği iddiasını taşımaktadır. 1927 yıı nüfus sayımına bakıldığında Osmanlı'dan devralınan toplumda ciddi bir sınıf ayrımı bulunmamaktadır. CHP tek parti olarak yönetimi sürdürmesine karşın kendini demokratik olarak tanımlamaktadır. Çünkü ulusal bir parti olduğunu ve tüm toplumsal kesimlerin parti içinde var olabildiği inancıyla başka bir partiye gerek olmadığı düşüncesi üzerine hedeflerini, amaçlarını, politikalarını oluşturmuştur (Uyar, 2011:47-48).

Çok partili hayata geçiş denemelerinden ilki 1924-1925 yıllarında Terakkiperver Cumhuriyet Fırkası ve 1930 yılında Serbest Cumhuriyet Fırkası deneyimleri olmuştur. Ancak bu iki partinin de ortaya çıkmasıyla muhalif grupların bu partileri odak noktası olarak kullanması ve cumhuriyete yönelik tehdit oluşturdukları düşünülmüştür. İmparatorlukların yıkılıp yerine ulus devletlerin kurulmaya başladığı bu dönemde CHP kendini modernleşmenin ve ilerlemenin yegâne temsilcisi olarak görmekteydi. Çok partili demokratik bir yaşam ihtiyacı bu süreci sekteye uğratması bakımından CHP tarafından istenmeyen bir durum halini almıştır. Kendisi dışında örgütlenen, iktidara aday partilerin oluşması tehlikesine karşılık CHP, muhalif odakları kendine bağlamış ya da ortadan kaldırmıştır.

\section{1. İ̧ Politika}

Dünyadaki merkezileşme akımı sonucunda imparatorlukların yıkılması, dünyada liberal, sosyalist ve ırkçı eğilimlerin ortaya çıkmasına neden olmuştur. Yeni dönemde ülkeler bu ideolojiler çerçevesinde devlet sistemlerini ve yönetim yapılarını değiştirmek zorunda kalmıştır. Türkiye bu süreçte cumhuriyet gibi demokratik bir rejim oluşturmayı başarmıştır. Imparatorluk döneminden ulus devlet dönemine geçişte Mustafa Kemal Atatürk, öncelikli olarak Saltanatı ve onun kurumlarını tasfiye etmiştir. İç politikada Atatürk döneminin en önemli olayları, hilafetin kaldırılması, Şeyh Sait İsyanı, İzmir suikast girişimi, Menemen olayı ve çok partili siyasi hayata geçiş denemeleri olarak sıralanabilir.

23 Nisan 1920 tarihinde TBMM'nin açılması ile Anadolu'da yeni bir Türk Devleti kurulmuş, TBMM'nin üstünde hiçbir gücün kabul edilmemesiyle Osmanlı Devleti'ne son verilmiştir. 27 Ekim 1923 tarihinde Fethi Bey'in istifasıyla başlayan hükümet bunalımı, meclis çalışmalarını zorlaştırmış, 29 Ekim 1923 tarihinde de Cumhuriyet ilan edilmiştir. Yeni bir devlet oluşturulmuş fakat hilafet hâlâ kaldırımamıştır. Bu ikili yapı meclis içerisinde ve halk arasında fikir ayrılıklarına neden olmasından dolayı hilafet 3 Mart 1924 tarihinde çıkarılan bir yasayla kaldııımıştır. Halifeliğin 
kaldırılması meclis içindeki görüş ayrıııklarını su yüzüne çıkarmış, 17 Kasım 1924 tarihinde Terakkiperver Cumhuriyet Fırkası kurulmuştur. Fırkanın faaliyetleri uzun süreli olmamış, 5 Haziran 1925 tarihinde kapanmıştır. Bu karışıklıklar üzerine 13 şubat 1925 tarihinde Şeyh Sait isyanı çıkmış, aynı yıl 31 Mart tarihinde de bastırılmıştır. Bu gelişmeler üzerine Takrir-i Sükûn Kanunu çıkartılmış, isyancıları yargılamak için İstiklal Mahkemeleri kurulmuştur.

Atatürk döneminde yaşanan önemli iç sorunlardan biri de kendisine düzenlenen suikast girişimidir. Atatürk rejimine karşı olan bir grup faaliyetlerine gizli gizli devam etmiş, en son olarak Atatürk'e İmir seyahatinde suikast planlamışlardır. Bu plan Atatürk'ün bir gün geç gelmesi sonucu bozulmuş, sorumlular yargılanmıştır. Atatürk devrimleri ve değişen düzene karşı tepkilerin çoğalması çok partili siyasi yaşamı zorunlu kılmıştır. Bunun için Atatürk güvendiği arkadaşı olan Fethi Okyar'dan Serbest Cumhuriyet Fırkasını kurmasını istemiştir. Halk, kurulan partiye büyük ilgi göstermiş ancak rejim karşıtlarının odağına yerleşmesi sonucu Fethi Bey 17 Kasım 1930 tarihinde partinin faaliyetlerine son vermiştir.

Atatürk, milli mücadelenin başarıyla sonuçlanabilmesi, kurulan yeni devletin güçlü bir şekilde var olabilmesi için iç güvenliğin öneminin farkında olmuştur. İ̧̧ güvenlik politikaları halkın güvenliğinin ve huzurunun sağlanması için birincil şart olarak görülmektedir. Bunun için tavizsiz iç güvenlik politikalarının oluşturulması ve hayata geçirilmesi için gerekli çalışmalara başlanmıştır. Atatürk, güvenlik politikalarının belirlenmesinde ve oluşturulmasında bizzat ilgilenmiş, Osmanlı Devleti'nden ve Milli Mücadele'den çıkan güvenlik mekanizmasını harekete geçirmeye çalışmıştır. TBMM'de okunan hükümet programlarında iç güvenlikle ilgili konuların öncelikli olduğu görülmektedir. Öncelikli olarak İstanbul Hükümetinden bağımsız bir polis teşkilatının kurulması sağlanmaya çalışılmışır. Polis teşkilatı görevlilerinin milli mücadeleye inanan insanlardan oluşturulması, işgal edilen yerlerdeki jandarma ve polis teşkilatlarına sadece Türklerin istihdam edilmesinin sağlanması ve işgal kuvvetlerinin güdümünde olmayan bağımsız bir polis teşkilatının oluşturulması vb. uygulamalarla bağımsız iç güvenlik birimleri oluşturulmuştur (Dikici, 2017: 148-149).

Kuruluş yıllarında ekonomi politikalarına bakıldığında 1923-1929 yılları arasında ekonomiye liberal bir bakış açısının egemen olduğu görülmektedir. 1929 yılı dünya ekonomik bunalımından sonra ise 1930'lu yıllardan itibaren devletçi ekonomik politikaların uygulamaya konulduğu görülmektedir. Bu dönemden sonra devletçilik ilkesinin gereği olarak bir dizi yasa çıkarılmış, devlet öncülüğünde sanayileşme stratejisi belirlenmiştir. Tarım toplumundan sanayi toplumuna geçiş için 1933 yııında Birinci Beş Yıllık Sanayi Planı hazırlanmış, yabancı uzmanlardan destek alınmıştır. Sanayi sektörü 1930-1939 yılları arasında olağanüstü bir büyüme gerçekleştirmiştir. Devlet eliyle gelişme sonucunda ulaşım ve bankacılık vb. sektörlerin devlet elinde olmasından dolayı piyasalar ve fiyatlar üzerinde devletin denetimine yol açtığı görülmektedir (Gezer, 2020:19-20).

\subsection{Dış Politika}

Atatürk'ün dış ülkelerle ilişkiler konusunda temel ilkeleri bulunmaktadır. Bu ilkeleri gerçekçilik, devlet gücüne dayanma, güvenilirlik, milli barışın sağlanması ve korunması, barış̧̧ııı, çağdaşlaşma modeli olarak batıılışma, uluslararası devletler hukukuna uygunluk, karşııklı güven ve iş birliği, dengeli dış politika ve fırsatçıık olarak sıralamak mümkündür. Atatürk, dış politika konusunda hedefler ve güçler arasında denge kurmayı hedefleyerek politikalarını belirlemiş ve kendi sözleriyle 'yurtta ve cihanda sulh' düşüncesini sağlamaya çalışmıştır. Bağımsızlık ve güvenlik için Londra Konferansı'ndan sonra dış politikasını denge üzerine konumlandırmıştır. Karşııklı güven ve iş birliği anlayışıyla beraber Sovyetler Birliği ve ideolojik olarak diğer tarafta olduğu kabul edilebilecek Batı medeniyetleriyle temasını kesmemiş, bu sayede Türkiye'yi çağdaş uygarlık olarak kabul ettiği Batı medeniyetleri seviyesine ulaştırdığı ifade edilmektedir (ilgazi et al.,2016:165-166).

Dış politikayı şekillendiren en önemli etken, Misak-ı Millî’nin diğer ülkelerce kabul edilmesi olmuştur. Bu bağlamda uygulanan dış politikanın iş politikayla da uyumlu olması ön planda tutulmuştur. Osmanlı Devleti döneminden farklı olarak bu dönemde dış politikanın milli güce dayandığı belirtilmektedir. Atatürk dış politikayı belirlerken uluslararası ilişkilerin gelişimine göre hareket etmiştir. Atatürk, Panturanizm ve Panislamizm görüşlerine karşıdır ve politikaları şekillendirirken maceracı değil gerçekçi olmuştur. Barış̧ıl dış politikaları sayesinde Hatay ve Musul sorunu, savaş nedeni olarak sayılmamıştır. Bunun bir yansıması olarak Türkiye 1932 yılında Milletler Cemiyeti'ne katılmış, Atatürk, devletler arası güvenliğin, dostluğun ve barışın tüm milletlerce uygulanması sonucunda dünyada genel barışın sağlanacağı görüşünde olmuştur. Barış̧ıl politikaların sorunun çözümünde yetersiz kalması durumunda Türkiye, kendini savunabilecek bir ülke konumunda bulunmaktadır. Kendi gücünün yetersiz kalması durumunda komşu ülkeler ile ittifak halinde olmak ve güvenlik paktları yapmak dönemin dı̧s siyasetinin önemli bir özelliği durumuna gelmiştir (Bolat, 2006:48-51). 
Cumhuriyet kurulduktan sonra Türk dış politikası, Lozan Barış Antlaşması'nda çözülemeyen konulara odaklanmıştır. İngiltere ile Musul, Fransa ile borçlar ve Suriye sınırı, Yunanistan ile mübadele sorunları ve kapitülasyonlar çözülemeyen başlıca sorunlar olmuştur. Daha sonra Musul hariç diğer konular Türkiye lehine çözümlenmiştir. Türkiye, bu sorunların çözümü ve barış politikalarının da etkisiyle 9 şubat 1934 tarihinde Balkan Antantı'nın kurulmasına öncülük etmiştir. 1936 yılında İngiltere ile Akdeniz Paktı çerçevesinde daha güçlü iş birliğinin önü açılmıştır. 8 Temmuz 1937 tarihinde ise Türkiye ve İngiltere ile yakın olan Orta Doğu ülkeleri, İtalyan tehdidine karşı Saadabad Paktı'nı imzalamışlardır. 20 Temmuz 1936 tarihinde Türkiye'nin boğazlarda egemenliğini tanıyan Montrö Antlaşması imzalanmış ve 1937 yılında Hatay sorunu çözüme kavuşturulmuştur (Gönlübol \& Kürkçüoğlu, 1985:458-461).

Sina Akşin, Türkiye'nin Atatürk dönemindeki yurtdışı itibarını demokrasinin gelişimine bağlamıştır. Akşin'e göre bu dönemde Türkiye'nin itibarı önemli bir düzeydedir ve bunu kanıtlayacak bazı göstergeleri sıralamıştır. Bunlardan ilki, Atatürk resmi ya da özel hiç yurtdışı gezisine çıkmamış olmasına rağmen Avrupa'nın birçok devlet adamı Türkiye'ye gelmiş olmasıdır. İkinci olarak 1920 yılında Avrupalı olmayan ve ayakta kalabilmiş 4 ülke olarak Çin, Habeşistan, İran ve Türkiye sıralanmaktadır ancak Türkiye hariç diğer ülkeler dış devletlerin saldırılarına uğramıştır. 1934 yılında İtalya Başbakanı Benito Mussolini, Türkiye'nin Avrupa ülkesi olduğunu ve emperyalist emellerine uzak olduğunu belirten bir açıklama yapmıştır. Üçüncü olarak 1933 yılından itibaren 142 Alman ve Avusturyalı bilim adamı Türkiye'ye gelmiş ve 1945 yılına kadar Türkiye'de kalmışlardır. Son olarak 1936 yılında Montreux'de toplanan ve Montrö Boğazlar Sözleşmesinin imzalandığı konferans, Boğazlar konusunda Türkiye'nin isteklerine uymuştur. Tüm bu göstergelerle Türkiye'nin dış ülkelerdeki itibarının gelişmiş bir demokrasi oluşturma çabasına bağlı olduğu ifade edilmektedir (Akşin, 1992:250-251).

\subsection{Atatürk Devrimleri}

Atatürk devrimlerini bir aydınlanma hareketi ve kalkınma modeli olarak değerlendirmek mümkündür. Kalkınma ile kast edilen ise bütünsel bir kalkınmadır. Kültür devriminin gereklerini karşılayan şekilde topyekûn bir kalkınmadan, her alanda bir yenilik düşüncesinden söz edebiliriz. Bu dönemde ahlak, hukuk, spor, sanat, ulaşım, enerji, sanayi vb. alanları kapsayacak şekilde geniş bir alana yayılan değişimler yapılmıştır. Atatürk için bir konservatuar açıması en az bir baraj yapımı kadar, kadın-erkek eşitliğiyle ilgili düzenlemeler bir demiryolu inşaatı kadar önemlidir. Atatürk devrimlerini hayata geçirirken toplumu ve düzeni yeni çağa uyum sağlama düşüncesindedir. Türkiye'nin aydınlanması bu bütünsel kalkınma modeli ile olmuştur. Maddi kalkınma yerine bütünsel kalkınma modelinin seçilmesi, Atatürk'ün yaptığı devrimleri sadece bir dönüşüm olmaktan çıkarıp toplumsal yapıyı ve toplumun bakış açısını değiştiren unsurlar içeren kültür devrimi alanına sokmaktadır (Akşin, 2002:107-108).

Cumhuriyetin kuruluş yıllarında hayat geçirilen devrim hareketleri ile önceki ıslahat hareketleri arasında önemli farklııklar bulunmaktadır. Atatürk'ten önceki ıslahat hareketleri daha çok dış etkenlerin zorlaması sonucunda genelde askeri alanda gerçekleştirilmiştir. Kökten bir değişim ve yön değiştirme yerine Batı ile Doğunun uzlaşma düşüncesi sonucu ıslahatlar gerçekleştirilmiştir. Daha önce gerçekleştirilen ıslahat hareketlerine kıyasla daha gerçekçi ve daha ilericidir. Ilerici olmasından dolayı halkın büyük bir kısmı devrimlerin derinliğini kavrayamamış, değişime direnmişlerdir. Bu nedenle yapılması planlanan değişimler 'halk için halka karşı' bir nitelik göstermiştir. Osmanlı Devleti'nin son yıllarında gerçekleştirilmeye çalışılan ıslahat, çekingen, açıkıktan yoksun, değişken bir davranışı ve uzlaştırmacı bir tutumu ifade ederken, Atatürk devrim hareketi, Batı dünyasının akılcı, laik ve milliyetçi anlayışına toptan yönelişi ifade eder (Cihan, 1981:120-121).

\subsection{Hukuki Rasyonel Bürokrasi Kurma Çalışmaları}

Atatürk döneminde yaşanan gelişmelerle demokratik bir toplum oluşturmak için adımlar atılmış, dönemin şartları göz önüne alındığında bazı gelişmeler günümüz demokrasilerinin özelliklerini karşılamasa da genel olarak demokratikleşme yönünde adımlar atıldığı görülmektedir. Günümüz gelişmiş demokrasilerinde Birinci Dünya Savaşıından sonraki dönemde kısıtlayııı, özgürlükleri engelleyen bazı uygulamalar olabilmiştir. Atatürk döneminde yapılan uygulamalar değerlendirildiğinde katı uygulamalara rastlandığı gibi ileri demokratik uygulamalara da rastlamak mümkündür. Demokrasinin gereği olarak bürokratik sistem de buna göre evrilmiştir. Osmanlı Devleti'nin son dönemlerinde başlayan rasyonel bürokrasi oluşturma çabaları, Atatürk döneminde hız kazanarak devam etmiştir.

Osmanlı Devleti döneminde Tanzimat'la başlayan reform ve batılılaşma çabaları modern merkeziyetçi bir devlet oluşturmanın ön adımları sayılabilir. Merkeziyetçi bir devlet yönetimi için en önemli unsur, bürokrat kökenli elit kesime dayanan bürokrasidir. Bürokrat kesim Kanun-i Esasi'nin ilan edilmesinden sonra yerini sağlamlaştırmış, 
Cumhuriyet yönetimine kadar yönetsel üstünlüğünü korumuştur. Cumhuriyetin kurulmasıyla bu patrimonyal özellik taşıyan bürokrasi, siyasal ve yönetsel yapılanmayı benimsemişlerdir. Türkiye'yi Kurtuluş Savaşı ile yıkılmaktan kurtaran modern bürokratik kesim, bu sefer de yeni bir ülke kurma misyonu edinmiştir. Cumhuriyetin ilk yıllarına denk gelen siyaset ve bürokrasinin tamamen özdeş olduğu bu dönemi bürokrasinin altın çağı kabul edilebiliriz. Cumhuriyet Halk Partisi bürokratların partisi olmuş, siyasete atılmak isteyenler bürokrasiyi basamak olarak kullanmıştır. Bu üstünlük çok partili hayata geçene kadar devam etmiştir (Yılmaz et al., 2013:280-281).

Atatürk, Osmanlı Devleti'nden bürokratik mekanizmayı miras almakla beraber çok geçmeden hantal ve işlevsiz olduğunu görmüş, sivil ve askeri bürokrasiyi değiştirme kararı almıştır. Osmanlı Devleti'nin halka uzak, merkeziyetçi bürokratik geleneği Cumhuriyetin ilk yıllarında da görülebilmektedir. Meclis içinde sivil, askeri ve siyasal kadrolar bir arada bulunmaktadır. Atatürk, öncelikle meclis içindeki sultana ve hilafete bağlı muhalefet oluşturabilecek kesimden kurtulma çalışmalarına girişmiştir. Bürokrasi üzerindeki yenilik adımlarının atılması tasfiye süreçlerini de beraberinde getirmiştir. Bu tasfiyeler sonucunda yeni oluşturulan bürokratik kesimin, otoriter, seçkinci ve Jakoben anlayış ile hareket ettiğini söylemek mümkündür. Oluşturulan bürokratik model tek parti iktidarını güçlendirecek şekilde oluşmuştur (Şavkılı \& Aydın, 2013:85).

Cumhuriyetin ilk yıllarında bürokrasinin, reformları geliştirerek devam ettirmek, yerleştirmek, korumak ve ekonomik kalkınmayı devlet öncülüğünde oluşturmak olmak üzere iki işlevi bulunmaktadır. Bu işlevleri gerçekleştirebilmek için de bürokrasiye geniş yetkiler ve güvenceler tanınmıştır. Ekonomik kalkınmanın devlet eliyle gerçekleştirilebilmesi için de bürokrasinin ekonomik yaşama müdahalesinin önü açılmıştır. Cumhuriyetin kurulmasından sonra tek partili yaşam sonucu devlet-parti özdeşliği olmuş, içişleri bakanı parti genel sekreteri, valiler de partinin il başkanı olmuşlardır. Bürokrasinin elitleşmesi ise cumhuriyetin ilk yıllarındaki Jakoben yaklaşım ile gerçekleşmiş, 'halkın halk için idaresi' anlayışı gündemde kalmıştır. Bu durum, merkez parti ve yönetim teşkilatında halka tepeden bakan bir bürokrasinin ortaya çıkmasına neden olmuştur. Atatürk döneminde askeri bürokrasi yerleşmiş, sivil bürokrasiye ancak İsmet İnönü döneminde geçiş yapılabilmiştir. Tek parti döneminde siyaset ve bürokrasi arasında organik bir bağ kurulmuş, bürokrasi ile siyasetin iç içe geçmiştir (Çevikbaş, 2014:85-86).

Türkiye'nin kuruluş yıllarında yeni bir bürokrasi oluşturma çabası, yeni bir yolsuzlukla mücadele çalışmasını da beraberinde getirmiştir. Bu dönemde yolsuzluk ciddi bir sorun olarak yeni devletin karşııına çıkmıştır. Rüşvetin toplumsal nedenleri, sosyokültürel yapı, devlet mekanizması ve ekonomik sorunlar olarak sıralanmaktadır. Cumhuriyetin ilk yıllarında sosyokültürel yapı Osmanlı'dan miras alınmış, savaş sonrası siyasal rejimin değiştiği bir dönem olmasından dolayı da devlet mekanizması ve ekonomi sorunlu duruma gelmiştir. Osmanlı́nın son dönemlerinde devlet otoritesinin zayıflamasından dolayı rüşvet suçunda bir artış ortaya çıkmış, yeni devletin kuruluş aşamasında da bu devam etmiştir. Kurtuluş Savaşı döneminde rüşvet ve diğer yolsuzlukla ile mücadele edebilmek için İstiklal Mahkemeleri kurulmuş, toplumda güven sağlamak için bu konularda ciddi önlemler alınmıştır. Bu dönemde farklı kamu görevlilerinin yolsuzluğa adının karıştığını söylemek mümkündür. Özellikle mültecilerin iskânında, askeriyede ve maliye alanındaki kamu görevlilerinde rüşvet sık rastlanan bir durum olmuştur. Henüz devlet düzeni yerleşmediği için davaları takip etmek, cezaları onamak vb. sorunlar ile de karşılaşılmıştır (Çelik, 2020:31-32).

\section{3. Çin Komünist Partisi ile Tek Partili Siyasi Yaşam}

Chen Duxiu, 1920 yılı Ağustos ayının sonlarında yedi üyeden oluşan Çin Komünist Partisi'nin(ÇKP) ilk şubesini kurmuştur. Eylül ayında Pekin'de bir diğer şube kurulmuş, anarşistlerin bu birimden ayrılmalarına izin verilmiş ve Kasım ayında üye sayısı 9'dan 15' yükselmiştir. Aynı ay Mao Zedong, Changcha, Hunan'da çok aktif bir şube ve büyük bir Sosyalist Gençlik Birliği kurmuştur. Mao güçlü bir eğitime sahip parlak bir genç aktivisttir. Daha sonra Çin Komünist Partisi'nin başına geçerek Çin Halk Cumhuriyeti'ni kurmuştur. Kasım 1920'de Çin'in merkezindeki Wuhan'da başka bir ÇKP şubesi örgütlenmiştir. Bu grup aynı zamanda, daha sonra saygın bir parti büyüğü olacak olan, Dong Biwu'yu da içermektedir. Diğer şubeler Tianjing ve Jinan'da ortaya çıkmış, modern devrimin beşiği olan Guangzhou'da ise son şube kurulmuştur. Bu ilk şubeler propaganda çalışmalarında, dergi ve broşürlerin yayılması ve dağıtılmasında, gençlerin ve iş̧̧ilerin eğitilmesinde önemli bir rol oynamışladır. 1921 yılı baharında ilk ulusal delegeler parti konferansı için planlar yapılmış, Temmuz ayı boyunca Birinci Parti Kongresi, Şanghay'da ve yakınında en az üç yerde 10 günlük bir süre içerisinde 15 oturum yapılmıştır. Bu yüzden 1 Temmuz partinin doğum günü olarak kabul edilip kutlanmaktadır (Uhalley, 1988:15-17).

Temmuz 1949 ve Ekim 1952 tarihlerinde Josef Stalin'in Mao Zedong'a önerileri doğrultusunda ÇKP, Ulusal Halk Kongresi'nin ilk toplantısını 15 Eylül 1945 tarihinde Pekin'de yapmıştır. Bu toplantıda yeni kurulan devletin yasal 
zemine kavuşması için anayasa kabul edilmiştir. Illk yapılan anayasada Stalin'in izlerini görmek mümkündür. 1.211 delegeden ve çoğu ÇKP üyesi olan meclis tarafından kontrol edilen totaliter bir hükümet kurulmuştur. Stalin'in gölgesinde gerçekleştirilen anayasa girişimleri, temsili organ konusuna katılmasa da Mao Zedong bu girişimleri desteklemiştir. Hatta Stalin öldükten sonra Sovyetler Birliği'nde ve Doğu Avrupa'da Stalinizme karşı çıkışlar başlamasına karşın, Mao isteklerini ertelemiştir (Li, 2001:28-31). Komünist bir devlet kurma yolunda Mao Zedong, Stalin ile iş birliği içinde olmuş ve Çin Halk Cumhuriyeti'nde tek parti yönetimini kurmuştur.

1949 yılında ÇKP’nin iktidara gelmesi Çin'de milliyetçi tek parti yönetimini komünist yönetimine dönüştürmüştür. Tek parti sistemi 20. yüzyılda dünyada yaşanan değişim sürecinin bir ürünü olarak otoriter hükümetin başlangıç biçimi olmuştur. Mao Zedong'un tek parti yönetiminin diğerlerinden ayırt edici özelliği devrimci yönünün olmasıdır. Devrimci dönüşümün gerçekleştirilebilmesi için kitle desteğini harekete geçirerek tüm sosyal ve politik kurumlara nüfuz etmek için yoğun bir örgütsel yapı oluşturulmuştur. ÇKP, siyasal gücün tek kaynağı haline gelmiş ve hükümet kurumları ve sosyal gruplar dâhil olmak üzere tüm siyasal kurumları meşrulaştırma ve kontrol etme hakkına sahip olmuştur. ÇKP’nin ilk üç anayasası mutlak parti liderliğinden bahsetmiş, bu sistemle parti aygıtı hem devlet hem de ekonomi ile birleşmiştir. Tüm hükümet yetkililerini ÇKP seçmekte ve tüm hükümet yetkilileri parti üyesi olmaktadır. Her devlet kurumunda, parti üyeleri bir parti komitesi ve çekirdek liderlik grubu altında örgütlenmiştir. Parti kadroları hükümet operasyonlarını dışarıdan değil içeriden denetlemektedir (Zhao, 1997:14).

\subsection{Mao Zedong Dönemi İç Politika}

Çin, Mao Zedong döneminde kitlesel kampanyalar ve radikal iç politikalar ile karakterize edilmektedir. ÇKP, iktidarını köylüler üzerinden kazanmış ve köylülere yönelik bir iç politika belirlemiştir. Çünkü ÇKP iktidara geldiğinde Çin'in \%90'ını köylü nüfus oluşturmaktadır. ÇKP, politikalarının etkisini artırabilmek için Nazi ve Sovyet propaganda yöntemlerini kullanmıştır. 1949-1976 yıllarında Çin, devrimci davayı destekleyen kitle hareketlerini tetiklemeye yarayan etkili ve radikal propagandasıyla ünlüdür (Albalak, 2014:1). Mao Zedong döneminin en önemli iç politikaları, köylülere toprak sağlamaya yönelik toprak reformu, Mao Zedong'un ideallerine uygun bir toplum yaratmak için giriştiği kültür devrimi ve ekonomik girişimler için Büyük ileri Atılım gösterilebilir.

1953 yılında Çin ekonomisi planlı ekonomik sisteme adapte olmuştur. Sovyet modeli bir kalkınma benimseyen Çin Halk Cumhuriyeti'ne uzmanlar gelmiştir. 1953-1956 yılları arasında bu çalışmaların sonucu olarak yatırım planlarının hızlanması ve artması, ayrıca tarım birliklerinin kurulması ve çiftçilerin bu birliklere büyük ilgi göstermesi olmuştur. Tarım toplumu olan Çin'de çiftçilerin üretici birliklerine katılmasıyla ülke ekonomisine önemli katkıları olmuştur. 1957 yııında yaşanan büyük değişime uyum sağlanabilmesi için Yüz Çiçek Kampanyası başlatılmış, aydın kesimin feodalizmden komünizme geçişi konusunda yardımların alınması amaçlanmıştır. Ancak bu dönemlerde Çinli aydın kesim ÇKP’nin politikalarını eleştirmektedir. Mao Zedong eleştirilerin yoğunlaşmasıyla bu duruma son vermiş ve yüzlerce kişi hapse atılmıştır. 1958 yılı 2. Beş Yılık Kalkınma Planı döneminde ise sanayi yatırımları ön plana çıkmış, demir-çelik üretimine yoğunlaşılmış ancak başarılı sonuçlar elde edilememiştir. 1966-1976 yılları arasında Kültür Devrimi uygulanmış, gençler aracılığıyla devrim ruhu tekrar canlandırılmaya çalışılmıştır (Timurtaş, 2018:56-57).

30 Haziran 1950 tarihinde Çin Halk Cumhuriyeti'nde Toprak Reformu Yasası yayınlanmıştır. Bu yasa ile komünist rejimin bir gereği olarak toprak sahiplerinin toprak aidiyetleri kaldırılmış, köylülere işlenmesi için toprak verilmiştir. 1951 yılına kadar eski toprak sahiplerinin topraklarına el konulmuş, topraksız köylülere ve küçük arazi sahiplerine toprak dağıtılmıştır. Eski arazi sahiplerinden toprağı sürmek zorunda olanlara da toprak verilmiştir. Tarım reformu ile Çin Halk Cumhuriyeti'nde sanayileşmenin temeli atıımış, tarımsal verimlilik artmıştır. Toprak reformu hareketine yaklaşık 310 milyon kişi katılmış, çok az toprağı olan ya da hiç olmayan 300 milyon köylüye 47 milyon hektarlık arazi dağıtılmıştır. Bunun yanı sıra tarım aletleri, besi hayvanları ve binalar da tahsis edilmiş, köylüler, yılda kira olarak ödedikleri 35 milyar kilogram tahıldan muaf tutulmuşlardır. 1953 yılı baharında toprak reformu Tayvan, Sincan ve Tibet dışında tüm bölgelere yayılmıştır (china.org.cn, 10.05.2021).

Büyük İleri Atılım girişimi, ilk kalkınma planından farklı olarak 'iki bacak üzerinde yürümek' stratejisini benimsemiştir. Bu stratejinin anlamı hem modern sektörün hem de geleneksel sektörün diğer bir anlatımla emekyoğun tarım sektörünün beraber büyümesidir. Birinci beş yıllık kalkınma döneminde tarım sektörünün göz ardı edilmesiyle başarısızlıklar ortaya çıkmıştır. İinci Beş Yıllık Kalkınma Planı döneminde Büyük Ileri Atılım girişimiyle hem tarım sektörü hem de sanayi aynı anda ön planda tutulmuştur. Mao Zedong, insanların günlük ihtiyaçlarının Okarşılanmasının kalkınma için ön koşul olduğunu anlamış, buna göre Büyük ileri Atııımı uygulamaya koymuştur. Ancak hedef olarak sanayi çıktısında \%25 artış gibi gerçekçi olmayan bir hedef konulması, bu kalkınma planının da başarısız 
sonuçlanmasına neden olmuştur. Hedefin yüksek konulması sonucunda ilk kalkınmada olduğu gibi bunda da üreticinin yaşam standartlarında ortaya çıkan gerileme göz ardı edilmiştir. Başarııılık sonucu oluşan kriz ortamı da iyi yönetilememiş, başarısızlı̆ın hem toplumsal hem de ekonomik yansımaları olmuştur. Planın uygulandığı yıllarda ekonomi \%27,2 düzeyinde gerilemiş, gayri safi yurtiçi hasıla 89,5 dolar seviyesinde kalmış, enflasyon \%15,2 ile çift haneli rakamlara yükselmiştir (Yalın \& Çetinbakış, 2019:130-131).

\subsection{Mao Zedong Dönemi Dış Politika}

Mao Dönemi dış politikasının öncelikle Sovyetler temelinde şekillendiğini daha sonra görüş ayrılıklarının yaşanmasıyla Batı dünyasıyla temasa geçildiği söylenebilir. Mao dönemi dünyanın iki görüş arasında kutuplaştığı Soğuk Savaş yıllarına denk gelmektedir. Amerika Birleşik Devletleri ve Sovyetler Birliği'nin dünyanın egemeni oldukları iddiasıyla birbirleriyle her konuda yarıştığı bir dönemdir. Bu dönemde diğer ülkeler de kendilerine bu iki devlet arasından bir kutup belirlemek zorunda kalmışlardır. 1949 yılında Mao Zedong ile ÇKP'nin iktidara gelmesi dış ilişkilerde Sovyetler Birliği'nin ağırlığının hissedilmesine yol açmıştır. Bunun dışında Çin Halk Cumhuriyeti için önemli bir olay da Kore Savaşı olmuştur. Dış politika incelenirken Mao iktidarının ilk yıllarını ve kültür devrimi yıllarını ayırmak mümkündür.

Çin, ÇKP'nin iktidara gelmesi ile ilk beş yılda dış ilişkilerinde Sovyetler Birliği'ne yaklaşmış ve ülkede istikrarı sağlama yılları olmuştur. Çin, ilk yıllarında Sovyetler Birliği'nin desteğiyle de uluslararası sisteme dâhil olmuştur. Bu dönemde Soğuk Savaş'ın komünist kutbuna Güney Kore'nin bağımsız olmasıyla Kuzey Kore de eklenmiştir. Sovyetler Birliği, Çin üzerinden Kuzey Kore'de de kontrolü ele geçirmiştir. Üç Çinhindi bölgesinde komünist rejim kurma iddiası ve daha sonra Tayvan üzerinde kontrol sahibi olmak için harekete geçilmesi, Amerika Birleşik Devletleri ile Çin'i karşı karşıya getirmiştir (Vyas, 2021:85-86). 1955 yılında ABD Başkanı Eisenhower, Çin Halk Cumhuriyeti'nin istilalarını önlemek için Formosa kararı ile komünist tehdidi önlemek için askeri birliklere silah kullanma yetkisi vermiştir. Daha sonraki süreçte Tayvan Boğazı krizi gergin kalsa bile Formosa'dan sonra baskı hafiflemiştir.

1955 yılından sonra dış politika, Çin liderliği için bir meydan okuma aşamasına tanık olmuştur. 1958 yılında Tayvan boğazlarındaki eylemleri nedeniyle Çin'in Sovyetler Birliği ile arası kötüleşmiştir. 1953 yllında Stalin'in ölümünden sonra Mao Zedong'un dış politika kararları keyfileşmiş, Stalin'in yerine parti başına geçen Kruşçev, Mao Zedong'u kınamıştır. Bunun üzerine Arnavutluk meselesi için oluşturulan konferansta Çin-Sovyet çatışması yaşanmıştır. Çin-Hindistan krizinde Sovyetlerin Hindistan'ı desteklemesi ilişkileri tamamen kötüleştirmiştir. Çin 1964 yılında tüm dünyada yankı uyandıran ilk nükleer enerjisini test etmiştir. Nükleer denemelerinden sonra ABD, Çin ile olan ilişkilerini değiştirmiş ve saldırmazlık anlaşması imzalanmıştır. 1971 yılında ABD Başkanı Nixon Çin'i ziyaret etmiş, Çin'e uluslararası sistemde hareket etme ve BM Güvenlik Konseyi'nde durma fırsatı vermiştir (Vyas, 2021:86-87).

Çin Halk Cumhuriyeti kurulduktan sonra yeni doğan komünist rejimin karşılaştı̆̆ı en büyük zorluk, hem yurt içinde hem de yurt dışında konumunu sağlamlaştırma noktasında olmuştur. Mao Zedong bu zorlu süreçte "yi bian dao" stratejisini diğer bir anlatımla iki blok arasından birini seçme stratejisini benimsemiştir. Bu bağlamda Sovyetler Birliği'ne sırtını dayanmış, kapitalist blok olan ABD'ye düşman olmuştur. Çin, Sovyet bloğunda güvenlik ve politika konusunda destek için sığınak bulabilmiştir. Bu strateji on yıl boyunca hüküm sürmüştür. On yıl sonunda Sovyetler bloğu ile gelişen anlaşmazlıklar Çin Halk Cumhuriyeti'nin strateji değiştirmesine yol açmış, 'iki hat savaşı' adı verilen ABD ve Sovyetlere karşı yüksek riskli bir yaklaşım içine girmiştir. 1970'li yılların başından itibaren ise hem Çin hem ABD, savaşların etkilerinden kurtulmak için de Sovyetler Birliği'ne karşı olmayı bir strateji olarak benimsemiştir. 1973 yılında Mao 'tek hat' stratejisini geliştirmiş, ABD, Japonya, Çin, Pakistan, İran, Türkiye ve Batı Avrupa'nın Sovyetler Birliği karşısında bir jeopolitik çizgi oluşturma ve Sovyetlerin genişleyen gücünü dizginleme ve koordine etme görevini üstlenmiştir. 1970'li yılların sonunda ABD, Sovyetler Birliği ile ilişkileri yumuşatma için Çin'i kullandığını söylemek mümkündür (Di, 2007:8-9).

Mao Zedong döneminin başlarında uygulanan 'tek tarafa yaslanma' stratejisi Çin Halk Cumhuriyeti'nin bağımsızlığını kaybedeceği ya da Sovyetler Birliği'nin uydusu olacağı anlamını taşımamaktadır. Aslında bu strateji Çin'in güvenliğini, egemenliğini ve bağımsızlı̆ını güvence altına almak için oluşturulan bir stratejidir. Sovyetler Birliği ile aralarının bozulmaya başlaması ile oluşan 'liangge quatou daren' (iki yumrukla savaşma) stratejisi, soğuk savaşın iki cephesine de bir karşı çıkış söz konusu olmuştur. Mao'nun bu stratejisi, yeni uluslararası güç yapılanmasına pasif bir tepkidir. Çin bu dönemde iki süper gücün hedefi haline gelmiş, ABD ve Sovyetler de Çin'i kontrol altına almak için iş birliğine girişmişlerdir. 1969 yılında Çin-Sovyet sınırında silahlı çatışmalar göz önüne alındığında, Çin liderleri en büyük tehdidin kuzeyden geldiğini fark etmiş̧ir. Çin, hayatta kalması için 'iki yumrukla savaşma' stratejisini değiştirmek 
zorunda kalmıştır. Mao, iki süper güç arasındaki çelişkiden faydalanabilmek için stratejisini değiştirmiş, ABD ile yakınlaşma kararı almışır. Yitiaoxian (birleşik cephe) de denilen bu strateji Mao'nun ölümünden sonra da devam etmiştir. Bu strateji Çin'in uluslararası sistemin bir parçası olmasını kolaylaştırmıştır (Cheng \& Zhang, 1999:95-99).

\subsection{Mao Zedong Devrimleri}

Çinli Marsistler özellikle Qu Qiubai ve Mao Zedong, kültürel devrimi hem teorize etmiş hem de uygulamışlardır. Çin'in kültür devrimi ilk olarak 1920'li ve 1930 'lu yıllarda Gramsci'nin hegemonya ve kültür üzerine düşünmesiyle aynı zamana denk gelmiştir. Kültürel devrim ile Çin'de Marksizm'in oluşmasına zemin hazırlanmıştır. Gramsci ve Çinli Marksistler arasındaki benzerlikler yüzeysel ve rastlantı değildir. Öncelikle 1920'li ve 1930'lu yıllar dünya çapında komünist ayaklanmaların yanı sıra kapitalist dünyada da faşizmin yükselişine yol açan ekonomik ve siyasal krizlerin yılları olmuştur. Gramsci'nin İtalya'sı faşist bir devlet haline gelirken, Çin, faşist Japonya tarafından tehdit edilmiş ve fiili bir istila yaşamıştır. Ikinci olarak hem Gramsci hem de Çinli Marksistler kapitalist moderniteye alternatif aramaktadırlar. Gramsci kapitalist, merkeze karşı az gelişmiş Güney ya da tarıma dayalı Doğu'nun sınırlarını belirlemiştir. Genellikle çevresel kabul edilen kültürel fikirler, sözcükler, ekonomik ve politik gücün merkezi yapısına karşı durmaktadır. Çağdaş kültürel çalışmalar 1960 'ı yıllarda önemli etkileri olan bir konjonktür durumuna gelmiştir. Çin, bu yıllarda Fransa'da ve ABD'de yayılan küresel toplumsal ayaklanmaları "Büyük Kültür Devrimi" olarak görmüştür (Kang, 1997:69-70).

1966 yılında kültür devriminin ilk aşamalarındaki mücadelenin, politikalar üzerindeki farklılıklarla ilgili olduğu görülmektedir. 1959 yılında Büyük İleri Atılım'da karşılaşılan sorunlardan dolayı Mao Zedong yukarıya doğru bir ivme kazanmak için Kültür Devrimi'ni başlatmıştır. Mao, uzun zamandır Kruşçev yönetimindeki Sovyetler Birliği'nde komünizmin neo-burjuvazi kapitalizmine dönüştüğüne inanmaktadır. Kültür Devrimi'nin başladığı 1966 yılında hem içte hem de dışta Mao Zedong çokça düşman kazanmıştır. Parti içinde de ayrılıkların başlaması sonucu 1967 yılı sonlarında rejimin kendi perspektifinden bakıldığında Kültür Devrimi, yaşlanmakta olan komünist bürokrasinin temel yapısal sorunlarını çözmeye yönelik bir çaba olduğu söylenebilir. Parti içindeki ve bürokrasideki kadroların kemikleşmesi ile daha muhafazakâr hale gelmeleri Kültür Devrimi'nin başlatılmasında önemli bir etkendir. Ülke içinde yeniden komünist ruhu canlandırmak için Mao Zedong'un başlattığı ve kendisine karşı olanlara karşı acımasız politikalar uygulattığı bu devrim başarısız olarak kabul edilmektedir (Johnson, 1968:2-4).

Mao'nun devrim düşünceleri, bizzat kendisi tarafından belirlenen '16 Maddelik Program' Politbüro kararına eklenmiştir. İlk madde, yeni bir aşama için 'dört eski' diğer bir anlatımla eski alışkanlıklar, fikirler, gelenekler ve kültür yerine tüm toplumun bakış açısını değiştirmek için yeni dörtlerin konulmasıdır. Kültür devriminin temel gücünü, işçiler, köylüler, askerler ve devrimci aydınlardan oluşan kitleler oluşturmaktadır. Parti komiteleri cesur olmalı ve cüretkârlığı her şeyin üstünde tutmalıdır. Kitleler kendi kendilerini eğitmeli ve özgürleştirmelidir. Parti liderliği, gerçeği keşfetmeli ve devrimci düşünceye güvenmelidir. Halk arasındaki çelişkiler ile bireyin kendisi ve düşman arasında kesin bir ayrım yapılmalıdır. Ayrıca sahte suçlamalara karşı önlem alınmalıdır. Parti kadrolarındaki sağ görüşlüler tamamen gözden düşürülmelidir. Parti, kitlelerle temas halinde olmalı ve eski eğitim sisteminde burjuva entelektüel egemenliğine son verilmelidir. Basında adı geçen parti üyelerinin değerlendirilmesi parti içinde yapılmalıdır. Bilim adamları, teknisyen ve personel, yabancı ülkeler ile ilişkileri olmadığı sürece çalışmalarına devam etmelidirler. Kültürel devrim sosyalist eğitim ile bütünleşmeli ve devrim Merkez Komitesi'nin Askeri Komisyonu ve Halkın Kurtuluş Ordusu ile yürütülmelidir. Kültür devriminin amacı, insanların ideolojisinde devrim yapmak, tüm çalışma alanlarında daha büyük, daha hızlı, daha iyi ve daha ekonomik sonuçlara ulaşmaktır (Deshpande, 1966:453-454).

\subsection{Mao Zedong Dönemi Çin Halk Cumhuriyeti Bürokrasisi}

Bürokrasi terimi, Mao ve takipçileri için Batı́daki anlamlarından farklı anlamlara sahiptir. Çin komünistleri geleneksel bürokrasinin nüfusun geri kalanından kendini ayırmasıyla ve diğer insanlardan farklı bir statü edinmeleriyle olumlu bir anlam taşımamakta, buna paralel olarak bürokrasiyi, ritüelizm olarak tanımlamakta ve ayırt edici statüsünü vurgulayarak sürdürülen bencil bir güç ve görev arayışı olarak tanımlamaktadırlar. Mao Zedong, bürokrasi ve bürokratlar hakkında keskin bir eleştirel görüşe sahiptir. 1933 yılında Mao Zedong, en büyük kötülüğün bürokrasi olduğunu belirtmiş ve bürokrasiyi lağım çukuruna benzetmiştir. Mao 1949 yılında iktidara geldiğinde Sovyet modelini örnek alarak ilerlemiş ancak 1950'li yılların sonlarında bu modelden memnun kalmamıştır. 1958 yılında Büyük ileri Atıım projesi başlatılmış, bu projenin de başarısız olması sonucunda bazı Çinli liderler başarısızlığı kendi sistemlerinden farklı olan rasyonel bürokratik gelişmenin üstünlüğüne bağlamışlardır. Mao böyle düşünmemekle beraber Kültür Devrimi'nde anti-bürokratik modelin Çin'in geleceği için benimsenmesi için girişimde bulunmuştur (Whyte, 1973:150). 
Mao Zedong 1970 yılında 'Twenty Manifestations of Bureaucracy' adlı çalışmasını yayınlamış ve bürokrasi anlayışını ortaya koymuştur. Mao'ya göre üst düzey bürokraside çok az bilgi bulunmakta ve onlar halkın fikrini almamaktadırlar. Bunun yanı sıra kitlelerden, gerçeklikten ve parti önderliğinden kopmuşlardır, her zaman emir verirler ancak verilen emirler genellikle yanlıştır. Otoriter bürokraside işlerini kavrayamazlar, öznel ve tek taraflıdırlar. Mao, bürokrasiyi çok meşgul olmalarına rağmen sert bir şekilde hiçbir iş yapmamak ile suçlamaktadır. Klasik bürokrasiyi efendilerin bürokrasisi olarak algılamakta ve insanlara eşit davranmadıklarını belirtmektedir. Mao'ya göre bürokrasi dürüst değildir, cahildir, merkezi hükümeti dolandırmaktadır. Bürokrasi sorumsuzdur, politikadan anlamazlar, işlerini yapmazlar ve sorumluluklarını yerine getirmemektedirler. Memur olup zorlukla geçinenler, ihmalkardır, her zaman hata yaparlar ve üstlerine kendilerini beğendirmek için uğraşırlar ama tembeldirler. Mao ayrıca bürokrasinin siyaseti tam olarak öğrenemediğini, aldatıcı ve yeteneksiz olduklarını belirtmiştir. Kırtasiyeciliğe vurgu yaparak, rüşvet ve yolsuzluğu vurgulamıştır. Bürokratların kamusal araçlarla özel amaçlarını tatmin ettiğini ve güç ve para için kendi aralarında savaştıklarını vurgulamıştır. Mao, bürokrasinin devrimci iradesinin zayıf olduğunu, hatalı eğilimlerinin gericiliği teşvik ettiğini ve kendi tarafında olanları istihdam ettiklerini belirterek bürokrasiyi eleştirmiştir (marxists.org, 30.05.2021).

Mao Zedong'un bürokrasiye bakışı olumsuz olmasına karşın Çin Halk Cumhuriyeti'nin kuruluş yıllarında bürokratikleşme büyük bir hızla ilerlemiştir. 1949-1966 yılları arasında Max Weber'in öngörülerini doğrular şekilde devlet bürokrasisinde büyük bir genişleme olmuştur. Bu dönemde tüm ekonomi ve toplum, eğitim, sağık, kitle iletişim araçları, kültür, sanat vb. alanlar bürokratik kontrole tabi kılınmıştır. 1949 yılından önce piyasa tarafından dağıtılan kaynaklar, Çin Komünist Partisi iktidara geldikten sonra bürokratik kurumlar tarafından tahsis edilmeye başlamıştır. Bireysel üreticiler kendilerini gitgide büyüyen büyük organizasyonlar tarafından ele geçirilmiş olarak bulmuşlardır. 1958-1960 yılları arasında özel teşebbüs faaliyetlerinin ve piyasa ekonomisinin kalan kalıntılarını ortadan kaldırmak ve böylece sosyal yaşamı bürokratik düzenlemelere daha tekdüze bir şekilde tabi kılmak için büyük çaba sarf edilmiştir. Çin toplumunun daha fazla yapısal bürokratikleşmesine yönelik büyük baskı, bu dönemde Büyük illeri Atılım döneminde olmuştur (Whyte, 1986:9-10).

Çin Komünist Partisi, yeni bir rejim oluşturma çabası içinde bürokratik sorunlar ile de uğraşmıştır. En önemli sorunlardan biri personel sorunlarıdır. Bürokratlar rejimin hedeflerine, değerlerine ve politikalarını bağlılıktan sıklıkla yoksundur. Bunun yanı sıra istenen devrimci coşku azdır ve yönetici ya da siyasal liderlerin astlardan bekledikleri çalışma azmi azdır. Bunların yanı sıra personellerde de yeterli yetenek ve teknik yeterlilik bulunmamaktadır. Personel sorunlarının yanında yapısal sorunlar da bulunmaktadır. Memurlar, siyasal liderlerin olmasını istediklerinden farkı özelliklere sahip oldukları için bürokraside disiplin ve kontrol sorunları yaşanmaktadır. Bunun yanında yöneticiler tam, doğru ve zamanında bilgi alamamakta ve performanslar daha çok para, zaman ya da çabaya neden olduğu için verimsiz olmaktadır. Mao dönemi bürokrasisinin halkla iletişimi konusunda da sorunlar yaşadığını söylemek mümkündür. Hükümetin sahip olduğu halk desteğini bürokratların da sağladığını söylemek doğru olmayacaktır. Halkın yönetime yabancılaşması sonucunu doğuran bu tür uygulamalara yolsuzluk ve rüşvetin yoğunluğu da eklendiğinde halkın bürokrasiden yana olumsuz tavır aldığı söylenebilir (Harding, 1981:3-8).

\section{Atatürk Dönemi Türkiye Cumhuriyeti ve Mao Zedong Dönemi Çin Halk Cumhuriyeti Karşılaştırmalı Analizi}

Dünyada merkezileşme ve ulus-devletleşme akımı başladığında Osmanlı Devleti ve Çin'deki Mançu Hanedanlığı yıkılmıştır. Bu devletlerin yıkılmasında dış faktörlerin önemli etkileri olduğunu ve bağımsız bir devlet kurulmasının istenmediği görülebilmektedir. Mustafa Kemal Atatürk ve Sun Yat-sen bu dönemde ortaya çıkmış, Türkiye'nin ve Çin'in siyasal bağımsızıkları için mücadele etmişlerdir. Atatürk'ün askeri dehası ve siyasal başarısı hem de karizmatik liderliğiyle toplumu örgütleyişi Türkiye'nin Birinci Dünya Savaşı sonunda bağımsızlığını kazanmasına yol açmıştır. Çin için aynı süreç işlememiş, Sun Yat-sen iyi bir siyasetçi olması dışında asker kimliğinin olmaması siyasal birliği sağlamasını engellemiş, onun yerine 1949 yıında Mao Zedong, Çin Komünist Partisi ile bu görevi yerine getirebilmiştir.

Siyasal birliklerini sağlama süreçleri birbirine benzemese bile Mao Zedong'un ulus inşası dönemiyle Atatürk'ün ulus inşası karşılaştırmalı olarak analiz edilebilecek kadar benzerlik taşımaktadır. ỉki ülke de siyasal birliğini sağladıktan sonra eski kurumların tasfiyesine girişmiş ve toplumun yaşam tarzlarını değiştirmek için kültür devrimi başlatmışlardır. İki lider bunları yaparken iki ayrı görüşe sahiptirler. Atatürk yönünü Batı́ya dönmüş ve politikalarını çağdaş batı medeniyetlerine göre düzenlemiş, Mao Zedong ise Batı karşıtı bir politika izlemiş, Batı'dan gelen politikaları reddetmiş, ülkesinde komünist bir düzen kurmaya çalışmıştır. Atatürk, dünyada yaygınlaşan serbest piyasa ekonomisine uyum sağlamaya, Mao ise sosyalist bir ekonomik düzen oluşturmaya çalışmıştır. 
İki lider de savaş sonrası dönemde, savaşta gösterdikleri başarılar sonucunda halk tarafından sevilip benimsenmiş, Atatürk'ün kurduğu Cumhuriyet Halk Partisi ve Mao Zedong'un kurduğu Çin Komünist Partisi iktidara gelmiştir. Tarım toplumu olan Türkiye ve Çin köylüleri ülkenin bağımsızlık başarısının başat gücü olmuştur. Atatürk ve Mao bu gerçeği unutmamış iktidara geldiklerinde yaptıkları ilk icraat, tarım reformu ile köylüye toprak dağıtmak olmuştur. Tek parti olarak iktidara gelen CHP ve ÇKP, ulus inşasının başarılabilmesi için uzun süre muhalefete izin vermeden iktidarlarını sürdürmüşler, Türkiye 1945 yılında çok partili siyasal yaşama geçiş yaparken Çin hâlâ tek parti yönetimi altındadır. İki parti de ülkenin kurtuluşunda rol almış kadrolardan oluşmuş, toplumdan kendilerine destek bulmaları zor olmamıştır. Ancak sistem değişimi döneminde karşılaşılan en büyük zorlukları ise topluma kendi felsefelerini benimsetmek olmuştur.

Atatürk dönemi Türkiye'sinde en çok karşılaşılan iç sorun, eski düzenin silinmesi ve alışılan dini örgütlenmelerin kaldırılmasında yaşanmıştır. Türkiye'nin aydın kesimi yüzünü Batı́ya çoktan dönmüşken halkın eğitim seviyesi ve eski alışkanlıkları, liderin görüşlerini radikal olarak algılamalarına neden olmuştur. Bu bağlamda Atatürk ve arkadaşları saltanatı ve hilafeti kaldıııken muhalefet odaklarının hedefi durumuna gelmiştir. Mao ve arkadaşlarının iç politika sorunlarına bakıldığında en önemli sorunun komünist toplum idealini oluşturmak ve bunu halka benimsetmek olduğu görülmektedir. Atatürk gibi Mao da parti içinde muhalefetle karşılaşmış ancak istenilen başarıya ulaşamayan iç politikalarıyla Atatürk'ten ayrılmıştır. Özellikle Büyük İleri Atılım ile sanayileşme konusunda attığı adımlar göreceli başarılı olsa da Atatürk'ün sanayi ve tarım politikaları kadar başarılı sonuçlar doğurmadığı ifade edilebilir.

Iki ülke de kuruluşlarında ve bağımsızlık mücadelelerinde Sovyetler Birliği'nden destek görmüşler ve uluslararası arenada yerlerini sağlamlaştırmışlardır. Daha sonra Sovyetlerden uzaklaşmış ve diğer ülkeler ile temasa geçmişlerdir. Dönemlerinin farklııkları göz önünde bulundurularak Atatürk dış politikada barış̧ıl ve yardımsever bir politika izlerken Mao Zedong çatışmacı ve savaş̧̧ı bir dış politika yürütmüştür. Mao'nun iktidarda olduğu dönemin soğuk savaş dönemine denk gelmesi ve komünist bir toplum olarak gittikçe liberalleşen dünyada varlığını kabul ettirebilmesi için nükleer silah yapımına geçmiş, dönemin iki gücü $A B D$ ve Sovyetlere karşı düşmanca bir tutumla kendini yalnızlaştırmışıı. Bunun aksine Atatürk tüm dünyada barışın egemen olmasını istemiş, bunun nedeni olarak da ülkenin uzun süren savaşlardan çıkması ve her anlamda yıpranmış olması şeklinde ifade edilebilir.

Yeni bir ulus inşası iki ülke için de toplumsal dönüşümü beraberinde getirmektedir. Modern devletlerin oluşmasıyla milletlerin benliklerine yapılan vurgu ve merkezileşme sonucunda ulus devletleşme süreci başlamıştır. Bu süreç sonucunda üç tip yönetim şeklinin dünyaya egemen olduğunu söylemek mümkündür. Öncelikli olarak demokratik ilkelere dayanan cumhuriyetler, ikinci olarak Karl Marx'ın ideolojisinden yola çıkan komünist devletler ve son olarak da faşizmin etkisi altındaki devletler ortaya çıkmıştır. Türkiye ve Çin, köylü desteğiyle bu merkezileşme akımından bağımsız bir devlet olarak çıkmayı başarmış, Türkiye'de cumhuriyet rejimi benimsenirken Çin Halk Cumhuriyeti'nde komünist rejim benimsenmiştir. Devletlerin yıkılması sonucu kurulan bu modern devletlerde toplum bu keskin değişime tam anlamıyla hazır olmamış, bağımsızlık mücadelesinde önemli rol üstlenen toplum, eski devlet alışkanlıklarının değişiminde zorlanmışlardır.

Kültür devrimi, halkların yeni oluşan düzene adapte olabilmeleri için gerçekleştirilen, 'halka karşın halkın iyiliği için' sloganına uygun bir uygulamadır. İki ülkede de hem siyasal dönüşüm yaşanmış hem de toplumun yaşayış tarzında ve sosyal-ekonomik durumlarında değişim yaşanmıştır. Atatürk ve Mao, kendi ideal toplum düşüncelerine ulaşabilmek için hızlı bir şekilde devrimleri ortaya koymuşlar ve toplumun bir an önce uyum sağlamasını istemişlerdir. Atatürk'ün başlattığı devrimler, toplumun değişim istemeyen kesimi tarafından şiddetli muhalefete maruz kalsa da başarılı olmuş, günümüz Türkiye'sinde devrimler ayakta kalmıştır. Mao'nun devrimleri ilk etapta başarısız olmuş gibi görünse de Çin Halk Cumhuriyeti ayakta kalmış, Sovyetler Birliği'nin dağılmasına karşın komünist bir düzeni sürdürebilmiştir. Bakıldığında toplumsal olarak istenen dönüşümün iki ülkede de sağlandığı görülebilmektedir.

Gelişim sürecinin benzerliğine karşın bürokrasi konusunda iki lider birbirinden farklı görüşlere sahiptir. Atatürk yüzünü batıya döndüğü için Batı'nın bürokrasisi olan Weberyen bürokratik modeli kurmak için çaba gösterirken Mao Batı́nın tüm değerlerini reddetmiş, özellikle bürokrasiyi sert bir dille eleştirmiştir. Ancak bu eleştirilere karşın Çin, hızı bir şekilde bürokratikleşmiş, ÇKP üye ve liderleri bürokratik elitleri oluşturmuşlardır. Rasyonel bürokrasiden oldukça geri duran Mao, bürokratikleşme eğilimini tersine çevirmek için Kültür Devrimi'ni başlatmıştır. Hem dış ilişkilerde hem de iç politikalarda Çin, Batı'nın değerlerine karşı çıkmış, komünist toplum düzeni oluşturmak için bürokrasisini de parti içinden kurarak buna destek olmaya çalışmışır. 
Çin Halk Cumhuriyeti, tek parti yönetiminin gerektirdiği şekilde üst düzey kamu kadrolarını parti içinden oluşturmuş, ideolojik olarak farklı kamu çalışanlarına izin vermemiştir. Bu kadroların önemli bir işlevi de parti ideolojisini halka yaymak ve benimsetmek olmuştur. Ancak karşılaştığı en büyük sorunlar, siyasal bağlılık, yetersizlik ve yolsuzluktur. Bunların sonucunda halkın kamu kadrolarına güveni azalmış, devletin meşruiyet zemini sarsılmaya başlamıştır. Mao döneminden başlayarak günümüz Çin'inde devam eden bu sorunlar Çin kamu yönetiminin ciddi bir sorunu olarak ortaya çıkmaktadır. Çözüm olarak parti içinden tasfiyeler yaşanmış olsa bile gereken disiplinin sağlanamaması sonucunda sorunlar tam anlamıyla çözülememiştir.

Atatürk dönemi Türkiye'si Mao dönemi Çin'inden farklı olarak rasyonel bürokrasi kurma çabasına girişmiştir. Bu süreçte bürokratik elitler oluşmuş, bu elitlerin en önemli toplumsal işlevi, topluma belirlenen ideolojileri aşılamak ve benimsetmek olmuştur. Ancak Mao'nun bürokrasi eleştirisinde belirttiği gibi Batı hayranı bürokrat kesimler halktan uzaklaşmış, onlara üstten bakar duruma gelmişlerdir. Bunun yanında Çin gibi Türkiye'nin de en büyük sorunu yolsuzluk olagelmiştir. İki ülkenin kuruluşundan bu yana yolsuzlukla mücadelede yeterince yolsuzluğun üstüne gidilmemiştir. Günümüzde hâlâ en büyük yönetim sorunu yolsuzluk olarak belirlenmiş, rüşvetin gelenek haline gelmesi sorununun önüne geçilmeye çalışılmıştır. Çok farklı biçimsel ve ideolojik politikalara sahip olmalarına karşın bürokrasi kurma, yetenekli kamu çalışanı bulma ve toplum tarafından meşruiyet kazanma konusunda aynı sorunları her iki ülkenin de yaşadığı ifade edilebilir.

\section{Sonuç}

Imparatorlukların yıkılıp merkezileşme akımının bütün dünyada başlaması ve Birinci Dünya Savaşı sonrası milliyetçiliğin ön plana çıkması ulus devletlerin oluşmasına zemin hazırlamıştır. Serbest piyasa ekonomisiyle daha erken tanışan Avrupa devletleri diğer ülkeleri açık pazar haline getirmek için baskı oluşturmuştur. En büyük baskıyı ise kendi kendine yetebilen, dışa kapalı ekonomiler görmüşlerdir. Bu dönemde benzer özellikler sergileyen Osmanlı Devleti ve Ming Hanedanlığı yıkılmış, yapılan reformlar da gelişmiş devletlerin olanaklarına ulaşamamıştır. Yıkılan devletlerin yerine Türkiye Cumhuriyeti ve Çin Halk Cumhuriyeti kurulmuştur.

Birinci Dünya Savaşı́ndan sonraki post-kolonyal dönemde Avrupa dışında bağımsızlık kazanabilen devlet sayısı sınırlı kalmıştır. Bağımsız olabilen devletlerin içinde olan Türkiye ve Çin, dünya tarihinde iz bırakan Weberci tanımla karizmatik lider özellikler sergileyen Atatürk ve Mao sayesinde olmuştur. Çin Halk Cumhuriyeti'nin imparatorluktan sonra bağımsızlık savaşını kazanan ancak siyasal birliği sağlamada sorunlar yaşayan Sun Yat-sen Atatürk ile eş değer kabul edilse de Mao Zedong bir ulusu inşa etmekle Atatürk'e daha yakın özellikler sergilemektedir. Ülkelerinde gerçekleştirmeye çalıştıkları dönüşümler hem dış aktörleri hem de iç aktörleri doğrudan etkilemiştir.

Atatürk ve Mao Zedong ülkeleri için kendi ideolojilerinin en iyisi olduğuna inanmış ve bu konuda toplumu, politikaları ve siyaseti etkilemişlerdir. Atatürk, Türkiye'nin geleceğini Batıda görmüş buna göre iç ve dış politikalarını şekillendirmiştir. Yaptığı reformlarla Türkiye'yi Avrupa'da sayılı ülkeler arasına sokmayı hedeflemiş, tarımı, sanayiyi ön plana çıkarmış, ekonomik ve sosyal kalkınmayı sağlama adına önemli girişimlerde bulunmuştur. Toplumdan ve meclisten itiraz sesleri gelse bile yolundan şaşmamış, belki de toplumun hazır olmasını beklemeden ilerici hamleler yapmıştır.

Mao Zedong, Atatürk'ün tam tersi bir şekilde diğer ülkeler ile iletişimini sınırı tutmuş, komünist bir toplum kurabilmek için adımlar atmıştır. Mao döneminde yaşanan devrimler başarısız kabul edilmiş, bazı devrimlerinde kıtlık yüzünden insan ölümleri bile ortaya çıkmıştır. Ancak Mao Zedong düşüncesinde vazgeçmemiş, ölmeden hemen önce bile komünizmi yaşatmak için girişimlerde bulunmuştur. Günümüz Çin Halk Cumhuriyeti hâlâ komünist partinin yönetiminde olmasına rağmen ideolojik olarak değişmiş, ekonomisini serbest piyasa ekonomisine uyarlayarak 'sosyalist piyasa ekonomisi' adı altında günümüz ekonomik modeline ayak uydurmuştur.

\section{Kaynakça}

Akşin, S. (1992). Atatürk Döneminde Demokrasi. Ankara Üniversitesi SBF Dergisi, 47(1), 245-252. https://doi.org/10.1501/SBFder_0000001531

Akşin, S. (2002). "Atatürk devrimleri ve yeni Türkiye'nin kuruluşu". Atatürkçü Bakış, 1(2), 105-116.

Albalak, A. (2014). The role of propaganda in Mao's domestic policy. GRIN Verlag: Erişim Adresi https://www.grin.com/document/284277 Erişim Tarihi: 20.05.2021 
Bolat, M. (2006). Genel Hatlarıyla Atatürk Dönemi Türkiye'nin İkili İlişkileri. Gazi Üniversitesi Kırşehir Eğitim Fakültesi Dergisi, 7(1), 45-74.

Cheng, J.-S., \& Zhang, F. (1999). Chinese Foreign Relation Strategies Under Mao and Deng: a systematic and comparative analysis. Kasarinlan: Philippine Journal of Third World Studies, 14(3), 91-114.

Cihan, E. (1981). Atatürk Inkılabı Yorumları. Istanbul Üniversitesi Hukuk Fakültesi Mecmuası, 45(1-4), 119-127.

Çelik, A. (2020). Arşiv Belgelerine Göre Atatürk Dönemi Rüşvet Vakaları ve Rüşvetle Mücadele. Pamukkale Üniversitesi Sosyal Bilimler Enstitüsü Dergisi(40), 17-35. https://doi.org/10.30794/pausbed.691963

Çevikbaş, R. (2014). Bürokrasi Kuramı ve Yönetsel İ̧̧levi. Ekonomi ve Yönetim Araştırmaları Dergisi, 3(2), 75-102.

Deshpande, G. (1966). China's Great Cultural Revolution. Economic and Political Weekly, 1(11), 453-455.

Di, D. (2007). Continuity and Changes: A Comparative Study on China's New Grand Strategy. Historia Actual Online(12), 7-18.

Dikici, A. (2017). Atatürk Dönemi İç Güvenlik Politikaları ve Türk Polis Teşkilatı. Türk Idare Dergisi(484), 115-154.

Gezer, G. (2020). Türkiye'de 1945-1950 Döneminde İç Politikanın Ekonomi Politikasına Etkisi. Elektronik Siyaset Bilimi Araştırmları Dergisi, 11(2), 18-31.

Gönlübol, M., \& Kürkçüoğlu, Ö. (1985). Atatürk Dönemi Türk Dış Politikasına Genel Bir Bakış. Atatürk Araştırma Merkezi Dergisi, 1(2), 451-474.

Harding, H. (1981). Organizing China: The Problems of Bureaucracy 1949-1976. California: Standford University Press.

Illgazi, A., Aksanyar, N., \& Bıyıklı, M. (2016). Atatürk Ilkeleri ve Inkılâp Tarihi. Ankara: Siyasal Kitabevi.

Johnson, C. (1968). The Cultural Revolution in Structural Perspective. Asian Survey, 8(1), 1-15. https://doi.org/10.2307/2642508

Kang, L. (1997). Hegemony and Cultural Revolution. New Literary History, 28(1), 69-86.

Li, H.-y. (2001). The Political Stalinization of China: The Establishment of the One-Party Constitutionalism, 1948-1954. Journal of Cold War, 3(2), 28-47.

Şavkıı, C., \& Aydın, T. (2013). Atatürk Döneminde Bürokrasinin Yeniden Yapılandırılması. Atatürk Araştırma Merkezi Dergisi, 29(87), 67-90.

Timurtaş, M. (2018). Çin Halk Cumhuriyeti'nin Ekonomil ve Siyasi Geçmişinin Bugünkü Gelişim Sürecindeki Rolü. Sakarya iktisat Dergisi, 7(1), 52-69.

Uhalley, S. (1988). A History of the Chinese Communist Party. California: Hoover Institution Press.

Uyar, H. (2011). Atatürk Dönemi İ̧̧ Politikası (1920-1938). S. İnan , \& E. Haytaoğlu(Ed.), Yakın Dönem Türk Politik Tarihi içinde (s. 43-77). Ankara: Anı Yayıncılık.

Vyas, P. (2021). Outline of Chinese Foreign Policy During Mao-Era. Researchgate: Erişim Adresi https://www.researchgate.net/publication/333531550_OUTLINE_OF_CHINESE_FOREIGN_POLICY_DURING_MAO _ERA Erişim Tarihi: 22.05.2021

Whyte, M. (1973). Bureaucracy and Modernization in China: The Maoist Critique. American Sociological Review, 38(2), 149-163. https://doi.org/10.2307/2094392

Whyte, M. (1986). Who Hates Bureaucracy? A Chinese Puzzle. Erişim Adresi www.umich.edu: https://deepblue.lib.umich.edu/bitstream/handle/2027.42/51105/337.pdf?sequence=1 Erişim Tarihi: 25.05.2021

Yalın, T., \& Çetinbakış, M. (2019). Uyuyan Dev Çin'in Yapısal ve Ekonomik Dönüşüm Süreci. Yönetim ve Ekonomi Araştırmaları Dergisi, 17(3), 123-145. https://doi.org/10.11611/yead.616934

Yılmaz, N., Doğan, K., \& İnankul, H. (2013). Tek Parti İktidarı Döneminde (1923-1946) Bürokrasi ve Siyaset Illişkisinin Weberyan Değerlendirilmesi. Atatürk Üniversitesi iktisadi ve Idari Bilimler Dergisi, 27(3), 263-284. 
Zhao, S. (1997). Political Reform and Changing One-Party Rule in Deng's China. Problems of Post-Communism, 44(5), 13-21. https://doi.org/10.1080/10758216.1997.11655746

www.china.org.cn. Erişim Adresi http://www.china.org.cn/features/60years/2009-09/15/content_18530605.htm Erişim Tarihi: 10.05.2021

www.marxists.org. Erişim Adresi https://www.marxists.org/reference/archive/mao/selected-works/volume9/mswv9_85.htm Erişim Tarihi: 30.05.2021 